\title{
Colorectal Cancer pTX TNM Finding v6 and v7
}

National Cancer Institute

\section{Source}

National Cancer Institute. Colorectal Cancer pTX TNM Finding v6 and v7. NCI Thesaurus. Code C60839.

Colorectal cancer in which the primary tumor cannot be assessed. (from AJCC 6th and 7th Eds.) 